\title{
Anti-proliferative effect of Cistus laurifolius on human cervical adenocarcinoma (Hep2C), human muscle rhabdomyosarcoma (RD), mouse fibrosarcoma (Wehi 164) cell line
}

\author{
Semra SOYDAM AYDIN *1, Ersin YÜCEL ${ }^{2}$ \\ ORCID: 0000-0002-1670-9677; 0000-0001-8274-7578
}

\author{
${ }^{1}$ Hacettepe University, Vaccine Institute, Department of Vaccine Technology, 06100 Ankara, Turkey \\ ${ }^{2}$ Eskişehir Technical University, Faculty of Science, Department of Biology, 26470, Eskişehir, Turkey
}

\begin{abstract}
In the current study; it was tried to determine antiproliferative activity of extract obtained from Cistus laurifolius leaves on different cancer cell type such as human cervical adenocarcinoma cells (Hep2C), human muscle rhabdomyosarcoma cells (RD), mouse fibrosarcoma cells (Wehi 164) by MTT Assay. The results indicated that Cistus laurifolius inhibited, in a dose-dependent manner, the proliferation of Hep2C, RD, Wehi 164 cells. Maximum antiproliferatif effects were observed in $1000 \mu \mathrm{g} / \mathrm{ml}, 500 \mu \mathrm{g} / \mathrm{ml}, 250 \mu \mathrm{g} / \mathrm{ml}$ concentrations of extract. These findings suggest that Cistus laurifolius extract could reduce proliferatif effect of cancer cell lines. Their use as potential anticancer agent needs further studies.
\end{abstract}

Keywords: Cistus laurifolius, human cervical adenocarcinoma cells (Hep2C), human muscle rhabdomyosarcoma cells (RD), mouse fibrosarcoma cells (Wehi 164)

Cistus laurifolius'un insan serviks karsinoma (Hep2C), insan kas rabdomyosarkoma (RD), fare fibrosarkoma (Wehi 164) hücre hatları üzerinde antiproliferatif etkisi

Özet

Bu çalışmada; Cistus laurifolius ekstraktının; insan serviks karsinoma (Hep2C), insan kas rabdomyosarkoma (RD), fare fibrosarkoma (Wehi 164) hücre hatları üzerinde antiproliferatif aktivitesinin MTT testi aracılığı ile belirlenmesi amaçlanmıştır. Sonuç olarak, Cistus laurifolius ekstraktının doza bağlı bir şekilde, Hep2C, RD, Wehi 164 hücrelerinin proliferasyonunu inhibe ettiği tespit edilmiştir. Maksimum anti-proliferatif etki $1000 \mu \mathrm{g} / \mathrm{ml}, 500 \mu \mathrm{g} / \mathrm{ml}$, $250 \mu \mathrm{g} / \mathrm{ml}$ ekstrakt konsantrasyonlarında gözlenmiştir. Bu sonuçlar, Cistus laurifolius'nin kanser hücrelerinin proliferatif etkisini azaltabileceğini işaret etmektedir ve antikanser ajan olma potansiyeli konusunda daha ileri çalışmalar yapilmalıdir.

Anahtar kelimeler: Cistus laurifolius, insan serviks karsinoma (Hep2C), insan kas rabdomyosarkoma (RD), fare fibrosarkoma (Wehi 164)

\section{Introduction}

Cancer is a multistage process which transformation of normal cell to step by step pre-cancerous lesion and malignant tumors. These differentiations are due to the interaction between genetic factors and environmental effects such as chemical carcinogens (aflatoxin, asbestos, arsenic etc.), biological carcinogens (infections from certain bacteria, parasites, viruses, or etc.) and physical carcinogens (ionizing radiation and ultraviolet and etc) [1, 2]. Today, despite

\footnotetext{
* Corresponding author / Haberleşmeden sorumlu yazar: Tel.: +903123053494; Fax.: +903123053493; E-mail: semra.aydin@ hacettepe.edu.tr

(C) Copyright 2021 by Biological Diversity and Conservation $\quad$ Received: 05.04.2021; $\quad$ Published: 15.08.2021
} 
considerable effort and treatment methods such as chemotherapy and radiotherapy, cancer is still important cause of death and morbidity on a global scale. Also these treatments have serious side effects such as diarrhea, pain, nausea, fatigue, vomiting and hair loss. For this reason, anti-cancer drug development studies maintain their importance and plant metabolites are seen options for anticancer drug development [3].

Plant metabolites had an essential role in traditional treatment with their complex mixture of valuable substance. Dry powders, extracts or different parts of them have been used for treatment of various disease include cancer [4,5]. İsolation or detection of plants active compounds lead to the discovery of so many drugs with therapeutic effect such as analgesic (morphine and codeine isolated from Papaver somniferum L.), antipyretic or fever reducing drug (quinine isolated from Cinchona sp.) the cardiac glycoside (digitoxin isolated Digitalis sp.), anticancer (paclitaxel isolated from Taxus sp., camptothecin or derivates topotecan, irinotecan, belotecan, gimetecan, 9-Nitrocampotethecn isolated from Camptotheca acuminate, epipodophyllotoxin, colchicine isolated from Colchicum autumnale L. , vincristine and vinblastine isolated from Catharanthus roseus). Recently, a substantial ratio of clinically used anticancer drugs are from natural resources and have been approved for treatment of acute myeloid leukemia, choriocarcinoma, lung cancer, testicular and ovarian cancers, bladder cancer and lymphoma etc [6-9].

Despite drug development studies and extensive resources are devoted to reduce cancer incidence worldwide, cancer cases continue to spread and are expected to increase by $70 \%$ in the next 20 years. This reveals a fundamental need to develop more effective and reduced side effected anticancer drugs from new sources are the focus of interest. Several Cistaceae species are consumed in traditional medicine as antiulcerogenic, antiinflamatory, antimicrobial, wound healing, antioxidant [10-13]. Especially, traditional Turkey folk medicine Cistus laurifolius have been used for diabetes [14]. The antiproliferative potential of C. creticus, C. libanotis, C. monspeliensis, C. villosus, C. salviifolius, partially evaluated against variable cancer cell lines, but to the best of our knowledge, there are few researches about anticancer activity of Cistus laurifolius [15-16]. In the current study; it was tried to determine antiproliferative activity of Cistus laurifolius L. on different cancer cell type such as human cervical adenocarcinoma cells (Hep2C), human muscle rhabdomyosarcoma cells (RD), mouse fibrosarcoma cells (Wehi 164).

\section{Materials and Methods}

\subsection{Plant Material and Extract Preperations}

The fresh leaves of Cistus laurifolius L. were collected from Tandır provence of Eskişehir, Turkey in in July, 2013. The identity of sample was authenticated from Herbarium of Anadolu University (ANES No. 15518). Cistus laurifolius L. extract was prepared according to the method of Sadhu et al. [17]. Leaves of Cistus laurifolius were firstly sun dried for 3 days and were further dried in an oven at $40 \pm 5 \circ \mathrm{C}$ for $48 \mathrm{~h}$. The dried leaves were griddled. $40 \mathrm{gr}$ powdered leaves bolied in $800 \mathrm{ml}$ water for 60 minutes and the extract were evaporated by vacuum evaporator and lyophilisated. Lyophilisate stored at $+4^{0} \mathrm{C}$ until using for MTT assay.

\subsection{MTT assay}

Human cervical adenocarcinoma cells (Hep2C), human muscle rhabdomyosarcoma cells (RD), mouse fibrosarcoma cells (Wehi 164) were cultured in Eagle's MEM medium, Dulbecco's Modified Eagle's Medium and RPMI 1640 medium, respectively. All culture medium supplemented with $100 \mathrm{U} / \mathrm{ml}$ penicillin and $100 \mu \mathrm{g} / \mathrm{ml}$ streptomycin and $10 \% \mathrm{FBS}$, under the conditions of $5 \% \mathrm{CO} 2$ at $37^{\circ} \mathrm{C}$. After cultivation, cells were harvested and plated in 96 -well plates at $1.0 \times 106$ cells $/ \mathrm{mL}$ in $100 \mu \mathrm{L}$. Allowed to adhere at $37^{\circ} \mathrm{C}$ in $5 \% \mathrm{CO} 2$ for $24 \mathrm{~h}$. Thereafter, $24 \mathrm{~h}$ incubation, mediums were replaced with $100 \mu \mathrm{L}$ different concentration of Cistus sp. extract $(1000 \mu \mathrm{g} / \mathrm{ml}, 500$ $\mu \mathrm{g} / \mathrm{ml}, 250 \mu \mathrm{g} / \mathrm{ml}, 125 \mu \mathrm{g} / \mathrm{ml}, 100 \mu \mathrm{g} / \mathrm{ml}, 50 \mu \mathrm{g} / \mathrm{ml}, 25 \mu \mathrm{g} / \mathrm{ml}, 12.5 \mu \mathrm{g} / \mathrm{ml}, 6.12 \mu \mathrm{g} / \mathrm{ml}, 3 \mu \mathrm{g} / \mathrm{ml})$ diluted with $14 \mathrm{mM}$ DMSO (Dimethyl sulfoxid) and incubated $37^{\circ} \mathrm{C}$ in $5 \% \mathrm{CO} 2$ for $24 \mathrm{~h}$. For positive and negative control; culture medium of cell and ammonium molybdate were used respectively. At the end of incubation period, $20 \mu \mathrm{l}$ (at a concentration of $5 \mathrm{mg} / \mathrm{ml}$ ) MTT (Methylthiazolyldiphenyl-tetrazolium bromide) was added to each well. After incubation for 3 hours, culture media in each well was aspirated and $100 \mu$ of propanol was added to dissolve the formazan products. Cell viability was assessed by MTT assay; the absorbance was read at a wavelength of $570 \mathrm{~nm}$ with respect to the reference wavelength at $620 \mathrm{~nm}$ using a spectrophotometer as previously described [18]. Two replicates of MTT assay was evaluated and all cell lines treated with different concentration of Cistus sp. extract. The results were analyzed by Softmax Pro 7.1 Software, 4 Parameter Logistic Assay, dose response curves were created and IC50 values were determined. 


\section{Results}

The cytotoxic effect of Cistus laurifolius extract on human cervical adenocarcinoma cells (Hep2C), human muscle rhabdomyosarcoma cells (RD) and mouse fibrosarcoma cells (Wehi 164) was determined by MTT assay. Cells were incubated for $24 \mathrm{~h}$ with the positive control and 1000, 500, 250, 125, 100, 50, 25, 12.5, 6.12, $3 \mu \mathrm{g} / \mathrm{ml}$. Dose dependent cytotoxic activities were observed in all the tested cell lines. Higher concentration, (1000, 500, 250 $\mu \mathrm{g} / \mathrm{ml}) \mathrm{of}$ Cistus laurifolius L. extract showed a significant cytotoxic effect. DMSO which used as diluent and $\leq 125 \mu \mathrm{g} / \mathrm{ml}$ Cistus laurifolius L. extract concentrations treated Hep2C and RD cells exhibited no cytotoxic effect (Figure 1, 2). All concentration of Cistus laurifolius L. extract observed antiproliferative effect on Wehi 164 cell line (Figure 3).

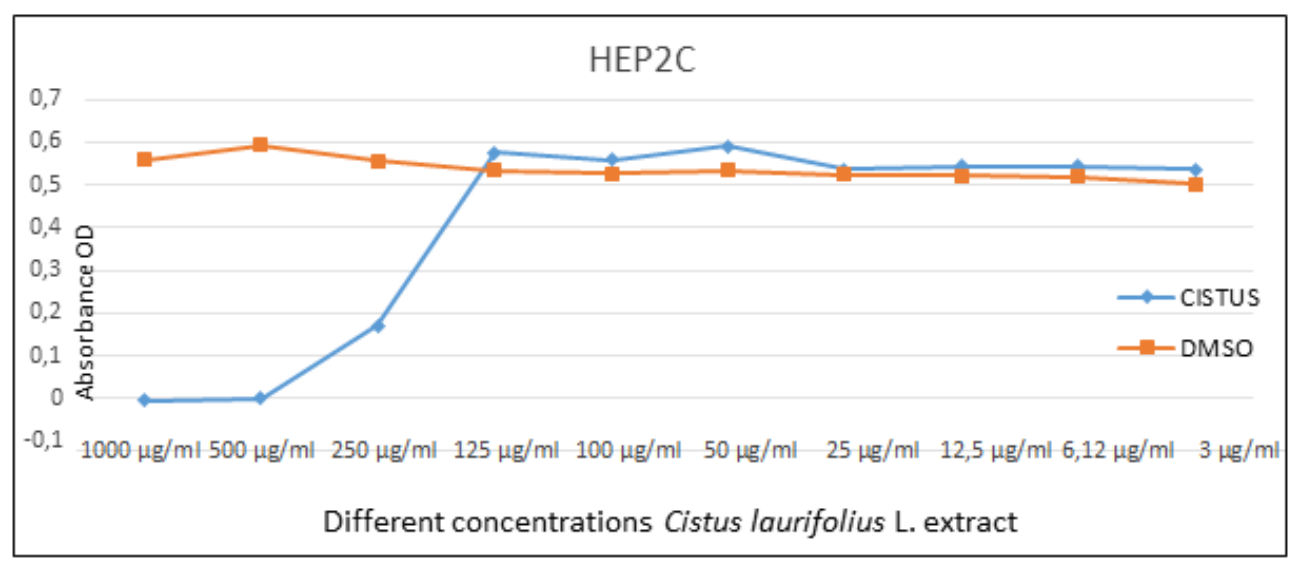

Figure 1. Effect of Cistus laurifolius extract on human cervical adenocarcinoma cells (Hep2C)

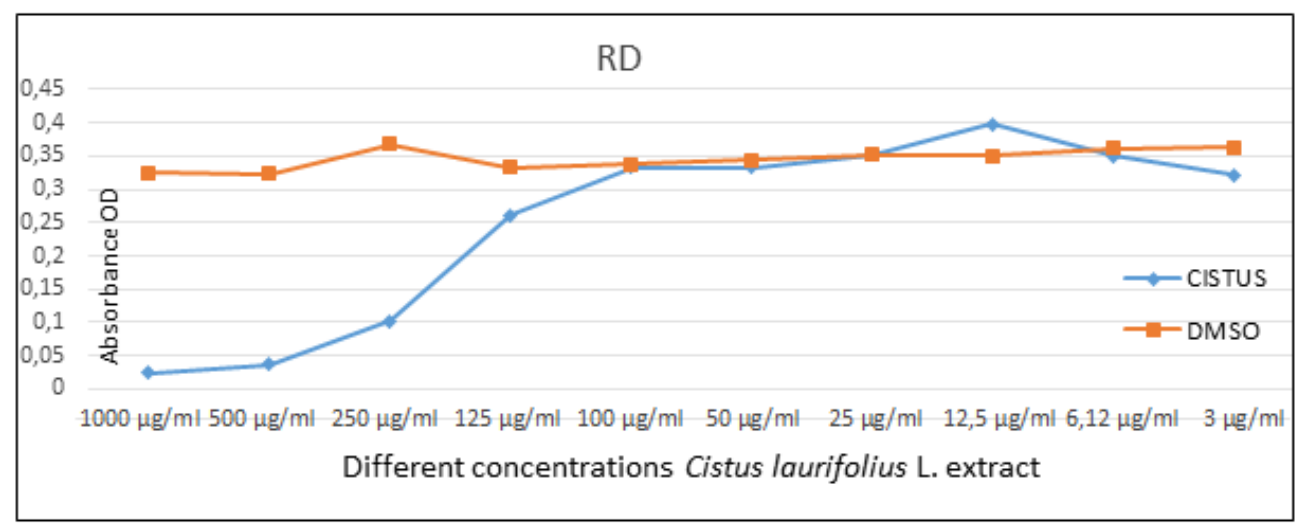

Figure 2. Effect of Cistus laurifolius extract on human muscle rhabdomyosarcoma cells (RD),

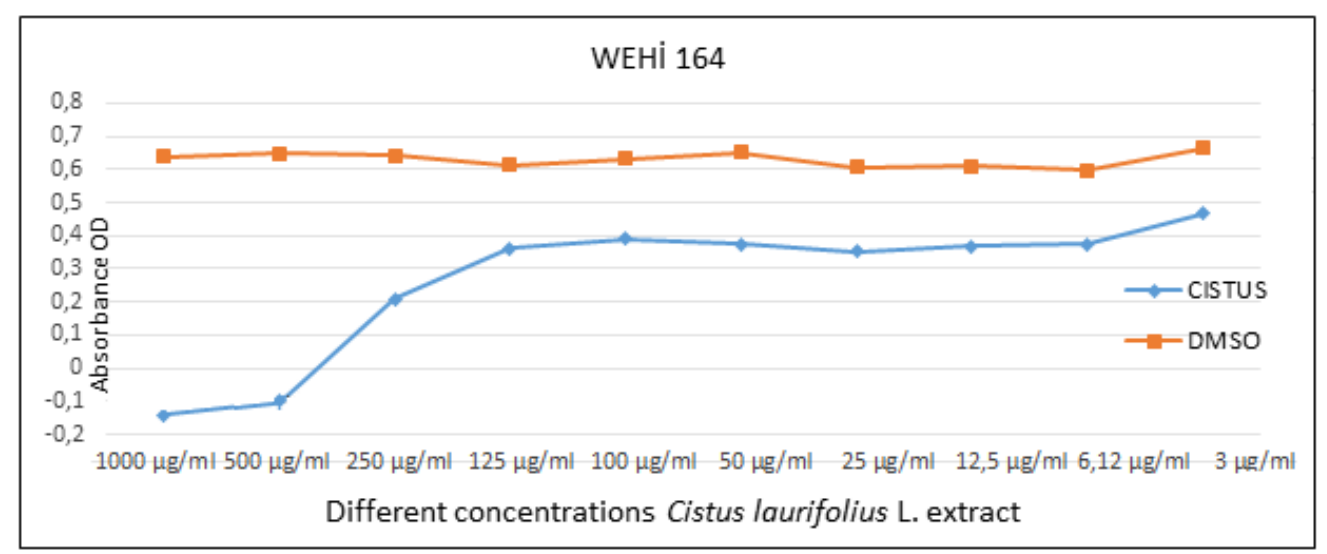

Figure 3. Effect of Cistus laurifolius extract on mouse fibrosarcoma cells (Wehi 164) 
The results are reported in Table 1 as $\mathrm{IC}_{50}$ values $(\mu \mathrm{g} / \mathrm{ml})$. Cistus laurifolius extract showed to be very toxic against all the tested cell lines with an $\mathrm{IC}_{50}$ around $200 \mu \mathrm{g} / \mathrm{ml}$ against Hep2C and RD, while it was more effective on Wehi $\left(\mathrm{IC}_{50} 127 \mu \mathrm{g} / \mathrm{ml}\right)$.

Table 1. IC50 Values ( $\mu \mathrm{g} / \mathrm{ml}$ of extract) for Antiproliferative Activity of Cistus laurifolius Towards Different Cells

\begin{tabular}{|c|c|}
\hline Cell Type & IC50 Values $(\boldsymbol{\mu g} / \mathbf{m l}$ of extract) \\
\hline Hep2C & 216,76 \\
\hline RD & 205,11 \\
\hline Wehi164 & 127,59 \\
\hline
\end{tabular}

Higher concentration $(1000 \mu \mathrm{g} / \mathrm{ml}, 500 \mu \mathrm{g} / \mathrm{ml}, 250 \mu \mathrm{g} / \mathrm{ml})$ of extract exhibited very strong cytotoxic activity in all the tested cell lines, while all lower concentration up to $3 \mu \mathrm{g} / \mathrm{ml}$ of extract showed remarkable amount of cytotoxic activity on Wehi cell line. Plant extracts show IC50 value $>300 \mathrm{ppm}$ considered as non-effective and not potential agent for anticancer drug development studies [9].

\section{Conclusions and discussion}

The phytochemical studies Cistus libanotis, Cistus villosus and Cistus monspeliensis extracts highlight their antiproliferative activity on human melanoma (A-375) and human breast cancer (MCF-7) cells [19, 20]. Cistus laurifolius is used as complementary medicine against diabetes in Turkey [21]. It is also used as anti-cancer, expectorant, anti-cold and dysentery [22]. Studies based on content analysis revealed that; Cistus leaf contains 49, 33\% water, 50,67\% dry matter, 32,95\% ash, 67,05\% organic matter, 1,74\% nitrogen, 10,87\% protein, 9,4\% fixed oil and $0,9 \%$ crude fiber [23]. Young shoots of Cistus contain 4,09\% water, 95,91\% dry matter, 33,53\% ash, 66,46\% organic matter, $0,68 \%$ nitrogen, $4,25 \%$ protein, $7,14 \%$ fixed oil, $1,44 \%$ crude fiber [24]. In the leaf known major compounds were identified as 3-O-methyl quercetin, 3,7-O-dimethyl quercetin, genkwanin, 3,7-O-dimethyl kaempferol, 3,4_-Odimethyl quercetin, apigenin, 3,4_- $O$-dimethyl kaempferol, ellagic acid, _-sitosterol-3- $O_{-}$-glucoside, quercetin 3-O-_rhamnoside, 5-O-p-coumaroyl quinic acid methyl ester, 1-(4-hydroxy-3-methoxyphenyl)-2-[4-(3-_-1 rhamnopyranoxypropyl)-2-methoxyphenoxy]-1,3-propanediol and 2,3-dihydro-2-(4_-_-1-rhamnopyranosyloxy-3_methoxyphenyl)-3-hydroxymethyl-7-methoxy-5-benzofuranpropanol [25].

Invitro cytotoxic activity of essential oil Cistus ladanifer was studied on human chronic myelogenous erythroleukemia (K562), human breast adenocarcinoma (MDA-MB-231 and MCF7), and human neuroblastoma cell lines (SH-SY5Y) and $\mathrm{IC}_{50}$ results were 49.6, 90.0, 128.1 and $92.8 \mathrm{ppm}$ respectively [9]. 0.5 mg/ml Cistus incanus L., Cistus monspeliensis L. extract was also induced a significant antiproliferative effect on normal human prostate cells (PZ-HPV-7) [26]. In another study, C. villosus and C. libanotis hexane extracts revealed no specific anticancer activity on murine monocyte/macrophages (J774.A1), human breast cancer cells (MCF7) and human melanoma cells (A-375). High antiproliferative activity of C. monspeliensis extract against A-375cell line with $\mathrm{IC}_{50}$ results $82.44 \mathrm{mg} / \mathrm{ml}$ at $24 \mathrm{~h}$ and $52.44 \mathrm{mg} / \mathrm{ml}$ at $72 \mathrm{~h}$ were determined [15]. To the best of our knowledge, there are no researches determined IC $_{50}$ results of Cistus laurifolius, therefore it is hard to compare our study findings with previously published research.

Previous studies reported that, rutin and gallic acid were determined as the main phenolic compounds of Cistus laurifolius [27]. Apigenin, quercetin and kaempferol are being increased in soils growing C. ladanifer. Also, in the extract of $C$. libanotis, quercetin 3,7,3',4'-tetramethyl ether (retusin) was detected as main compound. The major polyphenolic constitutes of Cistus incanus extract were determined as myricetin glycosides (\%61.8) and quercetin glycosides (\%9.28). Revealed through previous studies that quercetin triggers many cellular actions such as p53 activation, induction of caspase-mediated apoptosis and cell cycle arrest $[15,24]$. In other studies done the fact that aqueous extract of Cistus laurifolius has an acute antidiabetic effect and may be useful in controlling hyperglycemia 
[28, 29, 30]. It could be considered to say that Cistus laurifolius shows protective effects by preventing oxidative stress, apoptosis, and inflammation related to diabetes-induced complications, thanks to its rich bioactive content [27].

In this study we evaluated the antiproliferative effect of lyophilised aqueous extracts from Cistus laurifolius . Since few documented results are available about different species of Cistus genus, our studies have been initiated to elucidate this question. Results of these research deserve detailed investigation of chemical composition of extract and determination of pathway or action mechanisms of antiproliferation.

\section{Acknowledgements}

This paper was presented at 4th National Botanical Congress. 06-09 July 2017 Afyon-Turkey.

\section{References}

[1] Quadri, M.F.A., Saleh, S.M., Rashad Alsanosy, R., Abdelwahab, S.I., Tobaigy, F. M., Mohamed Maryoud, M., Al-Hebshi, N. (2014). Effectiveness of an Intervention Program on Knowledge of Oral Cancer among the Youth of Jazan, Saudi Arabia. Asian Pacific Journal of Cancer Prevention, 15.

[2] World Cancer Report: Cancer Research for Cancer Prevention. (2020). Edited by: Wild, C.P., Weiderpass, E., Stewart, B.W. ISBN 13 978-92-832-0448-0.

[3] Shin, S.A., Moon, S.Y., Kim, W.Y., Paek, S.M., Park, H.H., Lee, C.S. (2018). Structure-Based Classification and Anti-Cancer Effects of Plant Metabolites. International Journal of Molecular Science. 19, 2651.

[4] Li, W. (2002). Botanical Drugs: The Next New New Thing? Available at: http://nrs.harvard.edu/urn3:HUL.InstRepos:8965577 (accessed March 20, 2021).

[5] Robinson, M.M, Zhang, X. (2011). The TheWorld Medicines Situation 2011. Geneva:World Health Organization.

[6] Meng, F., Cheng, R., Deng, C., Zhong, Z., Intracellular drug release nanosystems. Materialtoday, 15-10.

[7] Fridlender, M., Kapulnik, Y. and Koltai, H. (2015) Plant derived substances with anti-cancer activity: from folklore to practice. Front. Plant Sci, 6,799.

[8] Dai, S.X., Li, W.X., Han, F.F., Guo, Y.C., Zheng, J.J., Liu, J.Q., Wang, Q., Gao, Y.D., Li, G.H., Huang, J. F. (2016). In silico identification of anti-cancer compounds and plants from traditional Chinese medicine database. Scientific Reports, 6, 25462.

[9] Najar, B., Shortrede, J. E., Pistelli, L., and Buhagiar, J. (2020) Chemical Composition and in Vitro Cytotoxic Screening of Sixteen Commercial Essential Oils on Five Cancer Cell Lines. Chemistry\& Biodiversity, 17, e1900478.

[10] Andres, A.l., Gomez-Serranillos, M.P., Iglesias, I., Villar, A.M. (1999). Effects of extract of Cistus populifolius L. on the central nervous system. Phytother. Res. 13, 575-579.

[11] Küpeli, E., Yesilada, E. (2007). Flavonoids with anti-inflammatory and antinociceptive activity from Cistus laurifolius L. leaves through bioassayguided procedures. J. Ethnopharmacol, 112,524-530.

[12] Barrajón-Catalán, E., Fernández-Arroyo, S., Saura, D., Emilio, G., Guillén, E., Fernández-Gutiérrez, A., SeguraCarretero, A., Micol, V. (2010). Cistaceaeaqueous extracts containing ellagitannins show antioxidant andantimicrobial capacity, and cytotoxic activity against human cancer cells. Food and Chemical Toxicology, 48, 2273-2282.

[13 Skoric, M., Todorović, S., Gligorijević, N., Janković, R., Živković, S., Ristić, M., Radulović, S. (2012). Cytotoxic activity of ethanol extracts of in vitro grown Cistus creticus subsp. creticus L. on human cancer cell lines. Industrial Crop and Products. 38, 153-159.

[14] Enomoto, S., Okada, Y., Güvenç, A., Erdurak, C.S., Coşkun, M., Okuyama, T. (2004) Inhibitory Effect of Traditional Turkish Folk Medicines on Aldose Reductase (AR) and Hematological Activity, and on AR Inhibitory Activity of Quercetin-3-O-methyl Ether Isolated from Cistus laurifolius L. Biol. Pharm. Bull. 27(7) 1140-1143.

[15] Jemia, M.B., Kchouk, M.R., Senatore, F., Autore, G., Marzocco, S., Vincenzo De Feo, V.D., Bruno, M. (2013) Antiproliferative activity of hexane extract from Tunisian Cistus libanotis, Cistus monspeliensis and Cistus villosus. Chemistry Central Journal, 7,47.

[16] Carev, I., Maravi'c, A., Ili'c, N., Culi'c , C.V., Politeo, O., Zori'c, Z., Radan, M. (2020). UPLC-MS/MS Phytochemical Analysis of Two Croatian Cistus Species and Their Biological Activity. Life, 10, 112. 
[17] Sadhu, S.K., Okuyama, E., Fujimoto, H., Ishibashi, M., Yesilada, E. (2006). Prostaglandin inhibitory and antioxidant components of Cistus laurifolius, a Turkish medicinal plant. J Ethnopharmacol 108:371- 378.

[18] Dyshlovoy, S.A., Menchinskaya, E.S., Venz, S., Rast, S., Amann, K., Hauschild, J., Otte, K., Kalinin, V.I., Silchenko, A.S., Avilov, S.A., Winfried, A., Madanchi, R., Bokemeyer, C., Schumacher, U., Walther, R., Aminin, D.L., Fedorov, S.N., Shubina, L.K., Stonik, V.A., Balbanov, S., Honecker, F., Amsberg, G.V. (2015). The marine triterpene glycoside frondoside A exhibits activity in vitro an in vivo in prostate cancer. Int. J. Cancer, 32, 1601-1618.

[19] Stępień, A. E., \& Ewa, A. (2017). Cytotoxic and anti-cancer activity of the Cistus species of herbal plants. European Journal of Clinical and Experimental Medicine, (2), 165-168.

[20] Jemia, M. B., Kchouk, M. E., Senatore, F., Autore, G., Marzocco, S., De Feo, V., \& Bruno, M. (2013). Antiproliferative activity of hexane extract from Tunisian Cistus libanotis, Cistus monspeliensis and Cistus villosus. Chemistry Central Journal, 7(1), 1-7.

[21] Yücel, E. 2008. Türkiye'de Yetişen Tıbbi Bitkiler 1, Cetemenler, ISBN 798-975-93746-3-1, Eskişehir.

[22] Yücel, E. (2014). Türkiye'de Yetişen Tıbbi Bitkiler Tanıma Klavuzu. Türmatsan, ISBN 978-975-93746-8-6, Eskişehir.

[23] Yücel, E., Çoban, Z. (2014). Pinar (Cistus laurifolius) Bitkisinin Etnobotanik ve Ekolojik Özellikleri ile Bazı Fitokimyasal Özelliklerinin Belirlenmesi, 22 ci Ulusal Biyoloji Kongresi, 23-27 Haziran 2014, Bildiri Özet Kitabı, Eskişehir.

[24] Sadhu, S. K., Okuyama, E., Fujimoto, H., Ishibashi, M., \& Yesilada, E. (2006). Prostaglandin inhibitory and antioxidant components of Cistus laurifolius, a Turkish medicinal plant. Journal of Ethnopharmacology, 108(3), 371-378.

[25] Emam, M.A., Khattab, H.I., Hegazy M.G.A. (2019). Assessment of anticancer activity of Pulicaria undulata on hepatocellular carcinoma HepG2 cell line. Tumor Biology, 1-10.

[26] Vitali, F., Pennisi, G., Attaguile, G., Savoca, F., \& Tita, B. (2011). Antiproliferative and cytotoxic activity of extracts from Cistus incanus L. and Cistus monspeliensis L. on human prostate cell lines. Natural Product Research, 25( 3), 188-202.

[27] Hacioglu, C., Kar, F., Kara, Y., Yücel, E., Dönmez, D.B., Sentürk, H., \& Kanbak, G. (2021). Comparative effects of metformin and Cistus laurifolius L. extract in streptozotocin-induced diabetic rat model: oxidative, inflammatory, apoptotic, and histopathological analyzes. Environmental Science and Pollution Research. https://doi.org/10.1007/s11356-021-14780-y.

[28] Kar, F., Hacioğlu, C., Kar, E., Kara, Y., Şentürk, H., Yücel, E., \& Kanbak, G. (2018). Cistus laurifolius, ameliorates the levels of insulin amylase and lipase in diabetic rats. Turkish Journal Of Biochemistry. 48 (S2), 029.

[29] Yücel, E., Kar, F., Hacıoğlu, C., Kar, E., Kara, Y., Şentürk, H., \& Kanbak, G. (2018). Acute antidiabetic activities of aqueous extract of Cistus laurifolius via metformin on streptozotocin-induced diabetic rats. Paper presented at the 2nd. International Plant Science and Technology Congress, Bodrum/Turkey, 07-10 October 2018.

[30] Hacioğlu, C., Kar, F., Kara, Y., Kar, E., Akkaya, NB., Şentürk, H., Yücel, E., \& Kanbak, G. (2018). The effect of Cistus L. on renal function, hepatic enzyme and lipid profile in diabetic rats, Turkish Journal Of Biochemistry. 48 (S2), 033. 